【カテゴリーI】

\title{
サン・カッシアーノ地区の特質からみたテアトロ・ミキエルと テアトロ・トロンの機能と実態について \\ STUDY ON THE CHARACTERISTICS OF THE PARISH OF SAN CASSIANO AND THE FUNCTIONS OF THE TEATRO MICHIEL AND THE TEATRO TRON
}

\author{
青木 香代子* \\ Kayoko AOKI
}

\begin{abstract}
This is the second part of the study on two theaters for comedies built in 1581 in Venice and closed in 1586, by researching the manuscripts kept in the Archivio di Stato di Venezia. The purpose of this thesis is to clarify the forms and the function of these theaters, according to consideration of the characteristics on the parish of San Cassiano. In addition, the usage of the term "teatro" in documents are pointed out to reveal the position of two theaters in the theatrical history of Italian Renaissance.
\end{abstract}

Keywords: Italy, Venice, Teatro Michiel, Teatro Tron, the parish of San Cassiano

イタリア, ヴェネツィア, テアトロ・ミキエル, テアトロ・トロン, サン・カッシアーノ地区

1. はじめに

本稿は、16 世紀後半、ヴェネッィアのサン・カッシアーノ地区に 建設されたテアトロ・ミキエルとテアトロ・トロンに関する一連の 研究の第 2 稿である。前稿では、劇場を所有した貴族に着目し、先 行研究で使用されてきた一次史料の再精查を行った。さらに、ヴェ ネツィア国立古文書館において公証人文書や書簡等、個人的な内容 が記される原史料を涉椫し、2つの劇場が君主や為政者の娛楽や権力 の誇示のために建設された同時代の他都市の劇場とは異なり、貴族 と役者が主体になり、有料上演によって収入を得ることをひとつの 目的とした劇場であったということを明らかにした”。

2 つの劇場はヴェネツィアにおいて最初に建設された常設の劇場 であり、またイタリア全体の中でも、最初期に建設された例である。 しかし、図面・絵画などの図像史料が現存しないことから、その様 態を明確にすることは極めて困難である。また先行研究の多くでも、 1582 年にフランチェスコ・サンソヴィーノが著した局高貴かつ唯一 の都市ヴェネツィア』における記述 ${ }^{2} に$ 依拠し、巨額の資金を投じて 建設された美しい劇場であったと認めているにすぎず、いまだ十分 な論証がされているとは言えない3)。

筆者は 2 つの劇場の建設は、劇場が新しいビルディング・タイプと して社会に位置づけられる以前の現象であるがゆえに、当時の都市 の社会や文化を映し出すものであると考えている。したがって本稿 では、2つの劇場が共にサン・カッシアーノ地区に建設されたことに 着目し、劇場の機能と形態に直接言及している一次史料の調查に加 え、地区の特質から劇場の機能と実態を検証する。さらに、前稿で 明らかにした 2 つの劇場の建設と上演が、同時期、他都市にみられ る君主の威信を示す祝祭での上演とは異なり、役者が主導した上演 であったことに重点を置く。そして、それに起因したテアトロ・ミ キエルとテアトロ・トロンの機能と様態を考察する。

\section{2. 位蒖}

テアトロ・ミキエルの位置については、1582 年の十分の一税申告 書 Condizioni di Decima に、コルテ・ダ・カ・ミキエルに存在したと 記されている中。現在はコルテ・デル・テアトロと呼ばれるこのコル テには、大運河に面した北東側の位置に、劇場を所有したミキエル 家とは別の家の所有であったカ・ミキエルと呼ばれるパラッツォが ある。また、コルテの南西側にはリオ・ディ・サン・カッシアーノ に面した建物 (A)、北西側には奥行きが約 9m の建物が面している。 北西側の建物はコルテに面するファサードに 12 世紀後半の典型的な 様式のアーチが残っている5)。さらに約 $9 \mathrm{~m}$ の奥行きでは、当初 200 個のボックス席が計画されていたテアトロ・ミキエルの敷地として は小さすぎる。したがって、テアトロ・ミキエルは、約 $21 \mathrm{~m} \times 22.5 \mathrm{~m}$ の大きさがある（A）の敷地に建設されたと考えることができる。

テアトロ・トロンが建設された位置に関しては、1582 年の十分の一 税申告書には具体的な記述がなく6)、サン・カッシアーノ地区の聖堂 の傍であったとする F.サンソヴィーノの記述が唯一の史料となる》。 しかし、18 世紀後半に行われたテアトロ・トロンの 2 度目の再建の際 に、建築家フランチェスコ・ボニョーロによって作成された敷地の実 測図等から、リオ・ディ・サン・カッシアーノとリオ・デッラ・マ ドンネッタに挟まれた一角（B）に存在したと推測できる8)。

1582 年の前回にあたる 1567 年の申告書からは、ミキエル家がサ ン・カッシアーノ地区に貸貸している倉庫と住宅を所有しているこ とがわかる9。一方、トロン家はサン・カッシアーノ地区に 70 ドゥ カーティで貸している「極めて古く、傷んだ家」を所有していると 記している ${ }^{10)}$ 。この記述はミキエル家、トロン家共に1567 年の十分 の一税申告書に見られるサン・カッシアーノ地区の物件としては唯 一のものである。また、同年に別の兄弟が作成した申告書の中にも サン・カッシアーノ地区の他の物件に関する記述はない。さらに、2
$*$ 東京芸術大学大学院美術研究科 博士後期課程 建築専攻 修士(芸術)
Doctoral Couse (Architecture), Graduate School of Fine Arts, Tokyo National University of Fine Arts and Music, M. Fine Arts. 


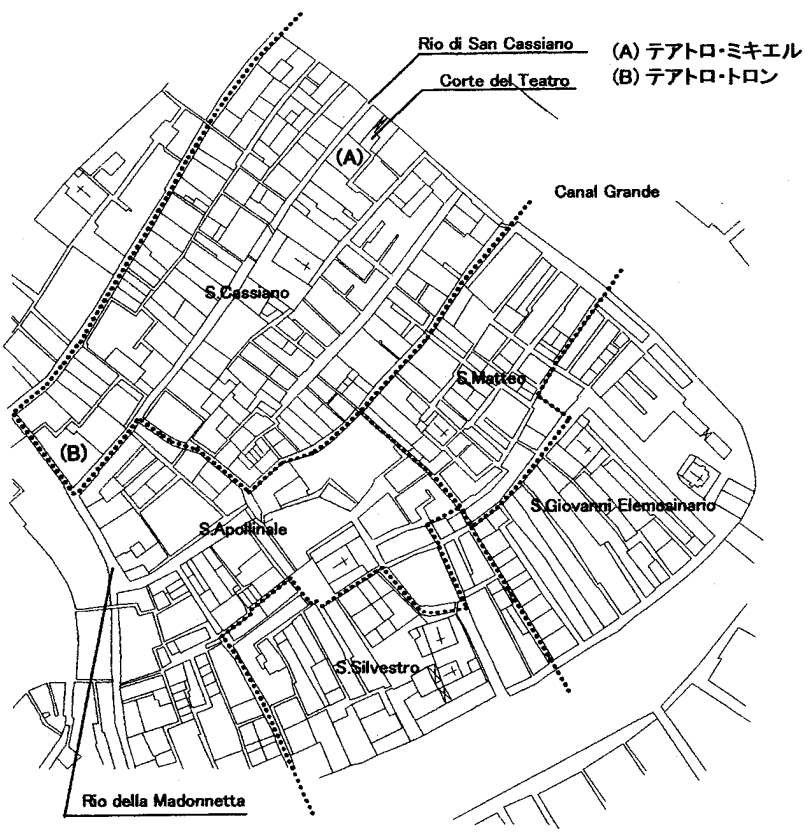

図1 サン・カッシアーノ地区と劇場の位置

度の申告が行われた 1567 年から 1582 年の間に、サン・カッシアー ノ地区における土地の売買・銥渡として両家が関わった記録が確認 できるのは、A.ミキエルが、わずか 5 ピエディの土地を購入したこ とを記す文書が存在するのみである ${ }^{11)}$ 。以上のことから、ミキエル家 とトロン家は、劇場を建設するために新たに土地を入手したのでは なく、1567 年の申告書を作成した際に既に所有していた場所に劇場 を建設したと考えることができる。

\section{3. サン・カッシアーノ地区について}

2 つの劇場が建設されたサン・カッシアーノ地区は、サンタ・クロ 一チェ区の中に位置し12)、リアルトと呼ばれるヴェネツィアにおける 交易と商業の中心地に近接する。そのため、商店 bottega、宿泊施設 としての機能を兼ねたオステリア osteria と呼ばれる居酒屋の類、食 堂 taverna、浴場 stufa 等が多く集まっていた ${ }^{13)}$ 。また、ヴェネツィア の中でも常に人口が集中した地区のひとつだったことが統計から明 らかで、ヴェネッィア全体の人口が約 148,600 人だった 1586 年には サン・カッシアーノ地区の人口は 2,838 人を数えた。また、人口密度 では、ヴェネッィアの平均が 330 人/ha であるのに対し、サン・カッ シアーノ地区では 1,144 人/ha であることからもその密度の高さを指 摘できる ${ }^{14)}$ 。

サン・カッシアーノ地区の 2 つの劇場では、淫らで不誠実な言葉 の使用がみられるとされた上演内容に加え ${ }^{15}$ 、劇場内で行われる行為 が十人委員会 Consiglio dei Dieciにおいて問題視され、上演が铰しく 制限され続けた。同委員会の議事録等においてスカンダロ scandalo と表現されている劇場内での行為は、1586 年に十人委員会が劇場の 閌鎖と解体を通達した際、その決定の要因のひとつとしても記され ている ${ }^{16}$ 。劇場内で起こっていたスカンダロが具体的に何を指したの かを明らかにするために、筆者は当時の犯罪等に関する多種の史料 を調查したが、その内容を明確にする記述は見当たらなかった ${ }^{17) 。 し ~}$ たがって、劇場内でのスカンダロとは、こうした犯罪関係史料に記 録されるような殺人、傷害あるいは筀盗事件などではなく、日常的
な騷ぎや醜事という程度のものであった可能性がある。

サン・カッシアーノ地区は、14 世紀半ばから 15 世紀にかけてカス テッレット castelletto と呼ばれる公営売春宿が設けられたサン・マッ テオ地区に隣している ${ }^{18)}$ 。16 世紀末の娼婦の居住地を登録した史料 からは、1514 年のリアルトの火災以降、サン・マッテオ地区周辺で 活動していた㛎婦が、若干の偏りはあるものの、都市内の広範な地 区に移り住んだことがわかる ${ }^{19)}$ 。しかしその後も娼婦にとって、宿屋 としての機能をもったオステリア等が重要な活動の場のひとつであ り続けたことから、サン・カッシアーノ地区を含むリアルト周辺で は特に活動が盛んに行われていたと考えられる20)。2つの劇場がコメ ディア・デッラルテの上演で人気のある劇団による喜劇上演のため に建設された劇場であったことは前稿で明らかにしたが、ヴェネッ イアでは 16 世紀初頭から、喜劇の上演を伴った貴族による祝祭に、 娼婦が出入りしていたことが当時の文書に記されている21)。したがっ て、サン・カッシアーノ地区に建設された 2 つの劇場にも、リアル 卜周辺で活動していた娼婦が出入りしていた可能性があり、史料上 に記されている劇場内で起こったスカンダロと呼ばれる騷ぎや醜事 に関わっていたことは十分に考えられる。

\section{4. 膚場の形態と特色}

テアトロ・ミキエルとテアトロ・トロンの形態について F.サンソ ヴィーノは、ひとつが棈円形、もうひとつが円形をした劇場であっ たとしている22)。また聖職者アントニオ・ペルシオも同様に、巨額の 資金を投じて建設された円形闘技場 anfiteatro の形態をした建物であ ると記している23) 24)。1581 年 2 月に公証人フランチェスコ・モンドが 作成した文書では、ジェロージ劇団の役者らが A.ミキエル兄弟に対 して舞台背景 scena と 200 個のボックス席 palco、役者のための 4 件 の住宅からなる喜劇上演のための場を建設することを求めている ${ }^{25)}$ 。 ボックス席の具体的な形態、数、構造等、建設後の様態を詳細に示 す史料は発見されていないが、テアトロ・ミキエルが建設されたと考 えられる約 $21 \mathrm{~m} \times 22.5 \mathrm{~m}$ の敷地に対して、役者が要求した 200 個のボ ックス席というのは極めて多い。また 1582 年 1 月 24 日の日付で、 劇場の建設主である A.ミキエルと大エフランチェスコ・ダ・セッラ ヴァッレの間でカッシアーノ地区のとある工事をめぐって訴訟が起 きたことを示す文書が存在する ${ }^{26)}$ 。この文書には、具体的に何の建設 に関する訴訟なのかは記されていないが、同時期に A ミキエルとそ の兄弟が建設に関わっていた記録は、サン・カッシアーノ地区のテ アトロ・ミキエル以外に確認できない。従って、この文書がテアト ロ・ミキエルの建設をめぐる訴訟であり、役者による注文どおりの 劇場が実現しなかった可能性があると考えられる。

ボックス席の様態については、十人委員会の議事録における記述 が唯一の史料となる。1583 年 1 月 5 日、1月 14 日、1585 年 2 月 8 日、1586年 1 月 14 日の記録から、後方にはおそらく通路があり、各 ボックス席は扉のようなもので閉じることで通路から内部での行為 が見えなくなる構造だったことがわかる ${ }^{27}$ 。同委員会から、劇場内で スカンダロが起こらないよう上演開始から全ての観客が退場するま での間ボックス席の後方を開け放ち、内部での行為が見えるように しておくよう度重悋て指示されていることから、劇場内でも特に扉 を閉めることで個室となるボックス席の中で行われる行為が、都市 の風紀を乱すとみなされていたに違いない。 
ボックス席に関する記述は複数残されている一方で、舞台背景に 関する記述は存在しない。劇場建設に先駆け、ジェロージ劇団の役 者側から要求された内容が記されている F.モンドによる文書にも、

「舞台 scenaをつくること」と記述されているのみである28)。そもそ もコメディア・デッラルテの劇団は、旅回りで上演を行う劇団で、

簡易な背景幕を携えて巡業し、仮設の舞台で上演することが普通で あった。1586 年 1 月 14 日に十人委員会から劇場の閉鎖と解体が言い 渡された際にも、わずか 15 日以内に痕跡残さず全ての舞台 scena や ボックス席を撒去することと指示されていることからも、大がかり な器械装置や舞台は存在せず、簢素な背景や舞台によって上演され た可能性がある。

表 1 は一次史料における 2 つの劇場に関する記述を一覧にしした のである。ここから 2 つ劇場については、一般的に劇場を表す “テ アトロ” teatro という語よりも、多くの場合 “喜劇を上演するための 場所” luogo per recitare commedie と表現されていることが明らかとな る。この他にも多くの史料において、単純に “部屋” stanzaや“ボッ クス席” palco という表現が使用されている。唯一、F.サンソヴィー ノが “テアトロ”という語を使用しているが、これは人文学の素養 をもった著述家だった彼自身によって出版された、ヴェネツィア案 内書という外向きの書としての特質によるものと考えられる ${ }^{299}$ 。

15 世紀末以降のイタリアでは、ウィトルウィウスの『建筑十書』 をもとに古代の建築が研究・解釈され、そのひとつとして劇場 teatro も盛んに研究されてきた。また、祝祭や演劇が催される際には、パ ラッツォ内の広間、中庭等に一時的な舞台や観客席を設えてきたが、 その中には理論家や建築家によって古代劇場の再現と専用劇場の実 現を試みる例もあった。こうした実験的な空間に関する当時の文書 では“テアトロ”と表現されることが多い一方で、ヴェネツィアの サン・カッシアーノ地区に建設された 2 つの劇場に関しては、表 1 に示すような別の表現が主に用いられている。このことから、2つの 劇場が時期としては他都市におけるルネサンス期の劇場研究の結実 として専用劇場が誕生し始めた 1580 年代に建設されたものの、それ とは異なる系譜にのるものと考えることができる30)。またそれは、サ
ン・カッシアーノ地区の 2 つの劇場が、人文主義者や建築家ではな く、役者によって建設と上演が主導され、興行収入を得ることをひ とつの目的とした劇場であったことと関係があると筆者は推察する。

\section{5. ロンドンの劇場から影雯を受けた可能性}

前稿では、サン・カッシアーノ地区の 2 つの劇場の建設に関して、 役者が強い発言権をもっていたことを明らかにした。イタリアの人 気役者ドルシアーノ・マルティネッリとトリスターノ・マルティネ ッリ兄弟 ${ }^{11}$ は、当時所属していた劇団と共に 1577 年から 1578 年にか

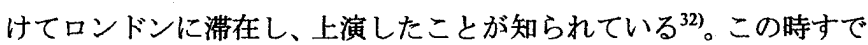
にロンドンには、イタリアに先駆けて 2 つの専用の劇場、ザ・シア

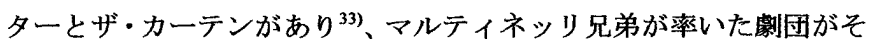
の劇場を目にした可能性は十分に考えられる。「古代ローマの形式 にならった木造の劇場で喜劇が上演されていた」と記されている口 ンドンの 2 つの劇場は、棈円形あるいは円形で、栈敷席と楽屋のよ うな機能をもつ役者のための施設が隣接していたと考えられている。 また、君主による劇場ではなく、所有者兼役者が有料上演によって 運営する劇場であった ${ }^{34)}$ 。の特徴はいずれも、ヴェネッィアのテア トロ・ミキェルとテアトロ・トロンにみられる特幑と共通すること が指摘できる。

当時マルティネッリ兄弟が、どの劇団を率いてロンドンへ行った かは明らかになっていない。しかし、ヴェネツィアでテアトロ・トロ ンが建設される直前の 1580 年には、コンフィデンティ劇団の一員だ ったことが知られている。また E.K.チェンバースは、マルティネッ リ兄弟がロンドンに滞在した時期の前後にフランスでの上演が確認 できるイタリアの劇団は、ジェロージ劇団のみであることに着目し た。当時、イギリスへ渡るのにフランスを経由しなかったと考える のは困難であることから、マルティネッリ兄弟と共にロンドンに滞 在したのは、ジェロージ劇団であるとの見解を提示している ${ }^{35)}$ 。た、 ジェロージ劇団とコンフィデンティ劇団は同じ宮廷の祝祭で上演す る機会もあって、相互で役者の移動が頻繁にみられるなど、緊密な つながりを持っていたことが知られている ${ }^{36)}$ 。さらに、D.マルティネ

表1 テアトロ・ミキエルとテアトロ・トロンを表現する語

\begin{tabular}{|c|c|c|c|}
\hline 史料名 & 日付 & 記述者 & 原文 \\
\hline Archivio Notarile, Atti, b.8317, cc.106v--107v. & 1581.2 .2 & ジェロージ瀜団の役者 & $\begin{array}{l}\text {-uno luoco de raggion del cl.mo ms.Alvise Michiel et fratelli del q.cl.mo Pierantonio } \\
\text { posto in contra de S.Cassan in corte da cha Michiel in calle di boteri, per recitar le } \\
\text { loro comedie et, } \cdots\end{array}$ \\
\hline Consiglio dei Dieci, parti comuni, registro.36, c.9r. & 1581.9 .25 & 十人委貴会 & $\begin{array}{l}\text {... che li sia stata fabricato più d'un loco per recitare le loro inhonestissime } \\
\text { comedie... }\end{array}$ \\
\hline $\begin{array}{l}\text { D'Ancona, Origini del Teatro Italiano Vol.II, Roma, } \\
\text { 1891, vol.II, p.452 }\end{array}$ & 1581.10 .7 & P.モ-IJ & $\cdots$, nelli palchi di quelli due loghi fabricati $\cdots$ \\
\hline $\begin{array}{l}\text { F.Sansovino, Venetia città nobilissima et singolare, } \\
\text { Venezia, 1581, cc.75r.-v. }\end{array}$ & 1581 & F.サンソヴィーノ & $\cdots$ due Teatri bellissimi edificati, $\cdots$ \\
\hline $\begin{array}{l}\text { Dieci Savi alle Decime in Rialto, condizioni di } \\
\text { decima, Dorsoduro, b.172, fasc.1376 }\end{array}$ & 1582.3 & ミキエル兄弟 & Un luogo che fabricato già un anno per recitar comedie, $\cdots$ \\
\hline $\begin{array}{l}\text { Dieci Savi alle Decime in Rialto, condizioni di } \\
\text { decima, S.Marco, b.158, fasc.905 }\end{array}$ & 1582.3 & トロン兄弟 & in luoco da recitar le commedie $\cdots$ \\
\hline Consigitio dei Dieci, parti comuni, registro.36, c.181r. & 1583.1 .14 & 十人委䆩会 & $\cdots$ dal lueco dove si recitano. \\
\hline $\begin{array}{l}\text { Lettera di Francesco Andreini al duca Vincenzo } \\
\text { Gonzaga }\end{array}$ & 1583 & $\begin{array}{l}\text { F.アンドレイ二ニ } \\
\text { (ジェロージ謯団の役者) }\end{array}$ & $\cdots$, et in particolare della stantia di Venetia, $\cdots$ \\
\hline Consiglio dei Dieci, parti comuni, registro.38, c.81v. & 1586.1 .14 & 十人雬員会 & $\cdots$ nel luoge da loro fabricato far recitar comedie \\
\hline Consiglio dei Dieci, parti comuni, registro.38, c.81v. & 1586 & 十人娄员会 & $\cdots$ luoghi fatti fabricar da esse per recitar comedie $\cdots$ \\
\hline Consiglio dei Dieci, parti comuni, filza.161 & 1586 & A.トロン & $\cdots$, fabricar un luoco, da recitar comedie, $\cdots$ \\
\hline BNM., Ms., Marc., it., VII, 335(8232), c.38r.-v. & 1607 & A.ペルシオ(聖職者) & $\begin{array}{l}\text {-.Al tempo ch'io quivi dimoravo c'erano introdotte le comedie in modo, che per } \\
\text { esse era stato fato un' edificio di gran spesa a guisa d' un anfiteatro ove si } \\
\text { riduceva quasi tutta la nobilita, } \cdots\end{array}$ \\
\hline Archivio Notarile, Testamenti, b.1244, fasc.439 & 1616.7 .1 & G.B.ミキエル & $\cdots$ nel luoco della comedia a San Casan \\
\hline
\end{tabular}


ッリがマントヴァ公のグリエルモ・ゴンザーガに送った手紙には、ジ エロージ劇団とコンフィデンティ劇団を「私達の劇団」と表現して いることからも苟、、ルティネッリ兄弟がコンフィデンティ劇団だけ でなく、ジェロージ劇団にも関わっていたと考えることができる。

以上のことから、1577 年から 1578 年の間にマルティネッリ兄弟と 共にイギリスを訪れたジェロージ劇団あるいはコンフィデンティ劇 団の役者が目にしたロンドンの劇場の様子が、サン・カッシアーノ 地区の劇場建設に影響を与えた可能性があると言える。

\section{6. まとめ}

本稿ではヴェネッィアのテアトロ・ミキエルとテアトロ・トロンに 関して、その形態と機能に直接言及している一次史料の精查に加え、 2 つの劇場が建設されたサン・カッシアーノ地区の特質から劇場の実 態を検証した。さらに、劇場の建設と上演を役者が主導したという 事実に着目し、劇場の形態に与えた影響を考察した。本稿が明らか にしたのは以下の点である。

1)ミキエル家、トロン家共に、劇場建設のために新たに土地を入手 したのではなく、もともと所有していた土地に劇場を建設した。 しかし、サン・カッシアーノ地区は商業の中心地であるリアルト に近く、商店、オステリア、食堂などが多く、常に人が集まるこ とと、娼婦の活動が盛んであったことから、ミキエル家とトロン 家が偶然ではなく、意図的にサン・カッシアーノ地区に劇場を建 設した可能性が考えられること。

2) 2 つの劇場内の観客席は、後方の屝を閉めることによって完全な 個室のようになるボックス席であり、そこではスカンダロと呼ば れる日常的な騒ぎや醜事が起きていた。また、その騒ぎにサン・ カッシアーノ地区やその周辺のオステリア、公衆浴場等を活動の 場としていた娼婦が関わっていたと推察できること。

3) F.サンソヴィーノはテアトロ・ミキエルとテアトロ・トロンに ついて、「巨額の資金を投資して建設された実に美しい 2 つの劇 場」であったと記している。しかし実際には、簡単な背景幕を携 えて旅回りをし、比較的つつましい空間で上演することが普通だ った役者の主導で建設された 2 つ劇場は、固定された装置や背 景をもたず、舞台は極めて簡素だった可能性があること。また、

舞台よりもボックス席が重要な建築要素であったと考えられる。

以上から、十人委員会において度重ねて 2 つの劇場での上演不許 可が出された要因のひとつに、ボックス席の中で行われていた行為 が問題視されていたということが明らかとなる。またこのことは、 貴族らが必ずしも 2 つの劇場に、観劇だけの目的で通ったのではな いことを意味する。16 世紀後半のヴェネッィアでは、それまで貴族 個人のパラッツォの中で行われていた会合や集会に、リドット ridotto と呼ばれる集会場や遊技場として機能する空間が使用されるように

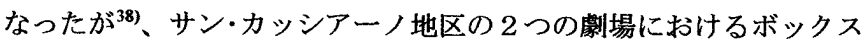
席もリドットと同様に貴族の新しい社交の場として使用されていた 可能性がある。ヴェネッィアでは 17 世紀に数多くの劇場が建設され た。その重要な建築要素であったボックス席は、貴族や上層市民に よって賃貸され、観劇のためだけではなく個人の密会や会合の場と しても使用されていたことが明らかになっている。サン・カッシア

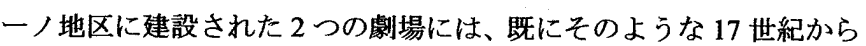
近代にかけての劇場の萌芽がみられたと推測できる。
また、テアトロ・ミキエルとテアトロ・トロンは、15 世紀末以降の イタリアで盛んに行われた劇場の研究と実験の結実として各地で建 設された劇場とは、同時期にも関わらず出自が異なる可能性がある。 コメディア・デッラルテは人文主義思想とも関わりがあったと考え られているが ${ }^{39}$ 、有料上演を行うことによって収入を得ることをひと つの目的としたジェロージ劇団、コンフィデンティ劇団の役者によ って建設が導かれた 2 つの劇場は、どちらかというと広場に一時的 な舞台を設え、仮設の観客席や周囲のパラッツォの中から観劇した 野外での上演、獣いじめ caccia と呼ばれる牛や熊を犬に負わせる競 技が行われたような、中世から直接引き継がれてきた見世物のため の空間に類するものであったと考えられる。また、そこには当時既 にロンドンに存在した劇場との類似点も確認できる ${ }^{40)}$ 。

役者によって建設が牽引されたテアトロ・ミキエルとテアトロ・ト ロンは、ルネサンス期における学問研究の一璵として、人文主義的 素養をもった当代屈指の建築家によって、為政者や教養ある上層市 民のために建設された同時期の他都市の劇場とはやや異なる系譜に よるものであったと考えられる。しかし、それは単に中世的な後進 性を示すものではなく、中世以来観劇のために設えられてきた栈敷 が、壁などで仕切られたボックス席に変容し、入場料を支払う貴族 や上層市民の個人的な娛楽や社交のための場として機能するように なる、17 世紀の劇場に先駆ける姿をとっていたのである。

注

1) 把稿「16 世紀後半ヴェネッィアにおけるサン・カッシアーノ地区の劇場建 設と上演について」，『日本建築学会建筑論文報告集』，第 617 号, 2007.7, pp.195-199.

${ }^{2)}$ Sansovino, F., Venetia città nobilissima et singolare, descritta in XII libri, Venezia, 1581, cc. $75 \mathrm{r}$.-v.

${ }^{3)}$ Mangini, N., I Teatri di Venezia, Venezia, 1974.; Mancini, F., et al., I Teatri di Venezia, tomo I, Venezia, 1996. 一方でE.J.ジョンソンは、F.サンソヴィーノが 2 つの劇場をサン・カッシアーノ地区で訪れるべきものとして記しているも のの、17 世紀以降に相次いで建設された劇場の上うに豪華な装飾が施され たのではないとの見解を示している。 Johnson, E.J., The short, lascivious lives of two venetian theaters: 1580-1585, Renaissance Quarterly, vol.LV(2002), p.944.

4) ASVe., Dieci Savi alle Decime in Rialto, Condizioni di Decima, San Marco, b.172, fasc.1376. A.ミキエル兄弟による申告。以下引用 [In S.Cassan; Un luogo fabricato gia un'anno per recitar comedie, le quali essendo state prohibite con le strettenze note ad ogn'uno, poca speranza si puo havere si trarne piu alcun utile, ... ]; Mangini, N., op.cit., p.22.

${ }^{5)}$ Maretto, P., La casa veneziana nella storia della città dalle origini all'ottocento, Venezia, 1986, pp.66-70.

${ }^{6)}$ ASVe., Dieci Savi alle Decime in Rialto, Condizioni di Decima, San Marco, b.158, fasc.905. E.トロンと A.トロンによる申告。

${ }^{7)}$ Sansovino, F., op.cit. cc.75r.-v.

${ }^{8)}$ ASVe., Giudici del Piovego, b.86., Mancini, F., et al., op.cit., pp105-114.を参照。

${ }^{9}$ G.B. ミキエルによる申告。ASVe., Dieci Savi alle Decime in Rialto, Condizioni di Decima, San Marco, b.128, fasc.995, 以下引用 [Ittem; mi atrovo in contra di San Cassan, in corte da $\mathrm{Ca}^{\prime}$ Michiel, uno magazen qual tien ad afito ser Zuanne da Logio et paga di fito ducati dodese alano, et di piu mi atrovo aver a galder dal dito ser Zuanne ducati cento. Ittem; una certa posta in contra di San Casan , in corte da Ca' Michiel del Tagliapietra, nela qual abita al presente dona Cecilia lavandera et paga ducati nove alano.]

10) E.トロンとその兄弟による申告。ASVe., Dieci Savi alle Decime in Rialto, Condizioni di Decima, San Marco, b.127, fasc, 419. 以下引用 [Item mi trovi, ma casa in San Cassan, nella quali habita ms Domenego da Gaghiani per affitto di ducati settanta, la qual casa è tanto vechia, et rovinata, ....

${ }^{11)}$ ASVe., Archivio Notarile, Atti., b.7829, 32r-33v.

12) 現在の区分では、サン・カッシア一ノ地区はサン・ポーロ区とサンタ・ク ローチェ区、2つの区にまたがっている。

${ }^{13)}$ Gallicciolli, G.B., Delle memorie venete antiche profane ed ecclesiastiche, libri tre, 
tomo 5, Venezia, 1795., Concina, E., Venezia nell 'età moderna: struttura e funzioni Venezia, 1989.; Scarabello, G., Le "Signore" della repubblica, in Le Cortigiane di Venezia, catalogo di mostra, Venezia, 1990. 公臬浴場は外科治療などにも用い られたが、混浴のものも多く、悪評高いものであったと考えられている。

14) この数值はジュデッカ区を除く6つの区を対象に算出。隣接するサンタ． マリア・マーテル・ドミ二地区、サンタポリナーレ地区、サン・シルヴェス ト口地区等も極めて人口密度が高かった。Gallicciolli, G.B., op.cit., p.135; Beltrami, D., Storia della popolazione di Venezia, dalla fine del secolo XVI alla caduta della repubblica, Padova, 1954, pp.37-43.を参照。

15）喜劇上演は 1508 年以降常に監視されつづけてきた。ASVe., Consiglio dei Dieci, Parti Comuni, registro.36, c.9r. 以下引用 [..., et però del 1508 a 29 di Decembre prohibitero con questo consiglio il recitar di comedie, egloge, et cose simili, perche in esse venivano fatti atti, et dette parole lascive, et inhoneste....]; Biblioteca Nazionale Marciana, Ms. Marc., it., VII, 335 (8232), c.38 v. 以下引用 [...nobili che pagavano $\mathrm{i}$ comediani che diccesero le più grasse per non dire più sporche cose che mai sapessero, ...]

16) ASVe, Consiglio dei Dieci, Parti Comuni, filza.152, filza 161.にも記述がある。ま た、役者が十人委員会に送った劇場での上演許可を請う内容の手紙にも、麖 場内でのスカンダロがおこらないよう、上演中はボックス席を開け放ってお くことが約束されている。ASVe, Consiglio dei Dieci, Parti Comune, Filza b.158; トスカーナの P.モーリも 2 つの劇場のボックス席の中でスカンダロ を伴う悪辣な行いがされていることを記している。D'Ancona, A., Origini del Teatro Italiano, Vol.II, Torino, 1891, p.452.を参照。

17) 制場内での行為について、以下の史料を調查した。Avogadori di Comune, Raspe, rr.3684-3686.; Consigio dei Dieci, Parti Comuni, r.34-41.; Consigio dei Dieci, Parti Comuni, filza, bb.139-161.; Capi Consiglio dei Dieci, Notatori, bb.24-28.; Signori di Notte, Capitorale, bb.1-1bis.; Cinque Anziani alla Pace, bb.1-8; Cassiere della Bolla Ducale, Grazie del Maggior Consiglio, r.5.

18) 1460 年にはマリピエロ家が政府と契約を結びヴェネツィアで 2 番目の公営 売春宿を設立。これは16 世紀初頭まで存続した。カステッレットに住まう 娼婦は、外出時間だけでなく、外出できる範囲、行動も厳しく定められ、監 視されていた。Scarabello, G., op.cit., pp.11-15.; Calza, C., Documenti inediti sulla prostituzione, tratti dagli archivi della repubblica veneta, Milano, 1869.

19)この史料はコッレール美術館の図書室に保管されているが、そのコピーが 以下の資料に所収されている。Lorenzi, B., Leggi e memorie venete sulla prostituzione fino alla caduta della repubblica., Venezia 1870.

20) オステリアの経営者にとっては、㛎婦が出入りすることによって增える収 益が、政府にとってもワインの売り上げによる税収は喜ばしいことであった。 Scarabello, G., op.cit., p.15.; 1580 年代のサン・カッシアーノ地区では、教区教 会の聖職者らまでもが肉欲の罪で逮捕されている。また、テアトロ・トロン のすぐ傍には、乳房の橋 ponte delle tette という名の橋があるが、G.タッシー ニよると、これは 16 世紀、橋のたもとの空辺に当時流行していた同性愛を 矯正する目的で乳房を露出した売春婦らを空辺に立たせたことに由来する。 ヴィッィアに残る地名の由来については Tassini, G., Curiosità veneziane, Venezia, 1990. (初版 1863 年)を参照。

21) Sanudo, M., Diarii, XVIII, 265.; Padoan, G., La commedia rinascimentale veneta, Vicenza, 1982. p.60; また、都市の中でも娼婦が多く集まるような地区で上演 されることも多かった。Taviani, F., L'ingresso della commedia dell'arte nella cultura del cinquecento, in Il Teatro nel Rinascimento, a cura di Cruciani, F., et.al., Bologna, 1987, p.327.

${ }^{22)}$ Sansovino, F., op.cit, cc. $75 \mathrm{r}$.-v.

${ }^{23)}$ Biblioteca Nazionale Marciana, Ms., Marc., it., VII, 355(8232), cc.38r-v. 以下引 用 [... Al tempo ch'io quivi dimoravo c'erano introdotte le comedie in modo, che per esse era stato fato un'edificio di gran spesa a guisa d'un anfiteatro ove si riduceva quasi tutta la nobilità, ...] しかし、この記述は劇場が解体された後の 1607 年のものであることから、A.ペルシオが実際に劇場を見て記したので はなく、F、サンソヴィーノの記述を参照した可能性も考えられる。

${ }^{24)} \mathrm{F}$.マンチー二は2つの劇場が建設されたと考えられる土地の形状から、テア トロ・ミキエルが円形、テアトロ・トロンが楕円形であったと論じている。 Mancini, F., et al.,op.cit.

25) ASVe, Archivio Notarile, Atti, b.8317, cc.106v-107v., 以下引用 [..., il prefato cl.mo ms.Alvise Michiel fo del cl.mo Pieroantonio facendo per nome suo proprio et per nome delli altri suoi fratelli, da una parte, et ms. Symon Coduri bolognese q. ms Filippo, ms. Terri ditto Horatio dalla Torre q.ms. Baldissera da Padoa, ms. Julio Pasquati da Padoa q. ms. Donado, et ms. Adriano Valerini da Verona q. ms. Andrea et compagni. nominati comici gelosi recitanti, dal'altra, sono devenuti all'infrascritta composition, et avendo con li patti, modi, condition infrascritte. Et prima, che prefato cl.mo ms. Alvise per nome suo et fratelli sia obligato nel soprascritto loco fabrichar una scena con palchi numero dusento in circa et altre comodità si' de (...) como de altri adecuamenti scenici che farano bisogno, (...), quatro stantie o quel piu che capita il luogo per comodità di essi recitanti a tute spese del prefato cl.mo ms. Alvise per li nomi soprascritti...]

${ }^{26)}$ ASVe, Archivio Notarile, Atti, b.8318, cc. $35 \mathrm{v}-36 \mathrm{v}$.

27) ASVe, Consiglio dei Dieci, Parti Comuni, registro.36, c.180v, 以下引用。[... che siano stati tutti li palchi del luoco aperti dalla parte da diedo, et traversati con cantinelle in modo che ciascuno che passerà possi veder per dentro di essi palchi, ...] 同様の記述が以下にも確認できる。ASVe, Consiglio dei Dieci, Parti Comuni, registro 36, c.181r.; registro 38, c.81r.; filza, b.158.

28) ASVe, Archivio Notarile, Atti, b.8317 cc.106v-107v.

29) F.サンソヴィーノについては以下を参照。Bonora, E., ricerche su Francecso Sansovino: imprenditore librario e letterato, Venezia, 1994.; Sforza, G., Francesco Sansovino e le sue opere storiche, Memorie della Reale Accademia delle Scienze di Torino, Torino, 1987, pp.27-66.

30) 同時期の例として、ヴィチェンツァのテアトロ・オリンピコ、フィレンツェ のウフィツィ内の劇場、500 人広間における劇場、サッビオネータのテアト ロ・オリンピコに関しては一般的にテアトロと表現されている。また 1565 年にコンパニーア・デッラ・カルツァのために A.パッラーディオによって ヴェネッィアにつくられた一時的な劇場もテアトロと表現されている。 ASVe, Senato Terra, filza 93.; Lucchesi, P., I teatri di Firenze, origini, storia, spettacoli, aneddoti e curiosità dei teatri, esistenti o scomparsi, che dall'epoca romana fino ad oggi hanno animato la vita della citttà, Roma, 1991.; Mazzoni, S., et.al., Il teatro di Sabbioneta, Firenze, 1985.; Mancini, F., op.cit., pp.67-85.を参照。 ただし、ヴェネツィアに限らず、喜劇上演が行われる空間を”部屋” stanza と 表現する例は他にも確認できる。また、テアトロという語がどのような定義 で用いられていたかについては、いまだ十分な議論がされていないため、こ れについては今後更に検討をしたい。 Mancini, F., et al.,op.cit., p.88.; Ruffini, F, Teatri prima del teatro, Roma, 1983, pp.19-20.を参照。

31) マントヴァ出身の役者。Enciclopedia dello spettacolo, fondata da Silvio D'Amico, vol. VII, Roma, 1975, pp.200-201.

${ }^{32)}$ Baschet, A., Les comédiens italiens à la cour de France sous Charles LX, Henri III, Henri IV et Louis XIII, Paris, 1882, p.80.; D'Ancona, A., op.cit., Vol.II, Torino, 1891, p.479.; Lea, K.M., Italian popular comedy, a study in the commedia dell'arte, 1560-1620, with special reference to the English stage, vol.2, Oxford, 1934.

33) 役者兼劇場の経営者であった Jバーベッジによって 1576 年に建設された常 設の劇場。ザ・シアターはその土地の所有者との争いが生じたため、1599 年に劇場の資材を用いて別の場所に再建される。この劇場がザ・グローブで ある。デ・ウィットによるスケッチが残っていることで知られるザ・スワン は 1595 年の建設である。このほかにも、エリザべス朝のロンドンには利益 をあげていたと考えられている獣いじめのための施設があった。その形態や 構造は不明な点が多いが、ヴェネツィア人 A.マーニョは「un loco rotondo circondato de palchi con li suoi coperti...」と記している。玉泉八州男『女王陡 下の興行師たち』芸立出版, 1984.; Dawson, G.E., London's bull-bainting and bear-bainting arena in 1562, in Shakespeare Quarterly, XV(1964), New York.; Chambers, E.K., The elizabethan stage, vol.2, Oxford, 1923.

34) 聖職者 J.ストックウッドによる記述。Yates, F.A., Theatre of the world, London, 1969., 邦訳：F.イエイツ, 藤田実訳『世界劇場』晶文全書, 1976.; p.120.; Chambers, E.K, op.cit; Wickham, G., Early english stages 1300 to 1660 , vol.2, London, 1969.エリザベス朝のロンドンの劇場研究は比較的進んだ分野では あるが、いまだ明らかにされていない部分も多い。

${ }^{35)}$ Chambers, E.K., op.cit., p. 260 .

36) Richards, K., The commedia dell'arte: a documentary history, Oxford, 1990, pp.61-66.; Taviani, F., $l l$ segreto della commedia dell'arte: la memoria delle compagnie italiane, Firenze, 1982,; Lea.K.M., op.cit.

${ }^{37)}$ D'Ancona, A., op.cit., pp.477-479.

38) 当時リドットという言葉は贵族の集会所や遊技場を指すと同時に貴族によ るサークルをも意味し、その空間をカジノと呼ぶ例もある。Padoan Urban, L., Le Compagnie della Calza: edonismo e cultura al servizio della politica, in Quaderni Veneti, Ravenna, 1987, p.126.; Zucchetta, E., Antichi ridotti veneziani: arte e società dal cinquecento al settecento, Roma, 1988, pp.10-13.

${ }^{39)}$ Povoledo, E., I comici professionisti e la commedia dell'arte, caratteri, tecniche, fortuna, in Storia della Cultura Veneta, vol.4/, Vicenza, 1983, pp.381-389.; Padoan, G., op.cit.

${ }^{40)}$ F.イエイツはエリザベス朝の劇場が古代劇場の再現の試みのひとつであっ たと主張しているが、その説の問題点も多く指摘されている。Yates, F.A., op.cit.; 玉泉八州男，前掲書,pp.105-173.を参照。

(2007年 5 月 10 日原稿受理， 2007 年 8 月16日採用決定 